\title{
ESTIMATION OF SEA WAVE HEIGHT IN TOAYA COASTAL WATERS, CENTRAL SULAWESI
}

\author{
Setiyawan ${ }^{\mathrm{a}, 1, *}$, Gracela Tangke Datu ${ }^{\mathrm{a}, 2}$, Syaiful Hendra ${ }^{\mathrm{b}, 1}$ Yuli Rahman ${ }^{\mathrm{c}, 1}$ \\ ${ }^{a}$ Civil Engineering Department, Faculty of Engineering Tadulako University, Palu Indonesia \\ ${ }^{\mathrm{b}}$ Information Technology Department, Faculty of Engineering Tadulako University, Palu Indonesia \\ ${ }^{c}$ Electrical Engineering Department, Faculty of Engineering Tadulako University, Palu Indonesia \\ ${ }^{1}$ setiyawanvip@yahoo.co.id *; ${ }^{2}$ gracela_tangkedatu@yahoo.com; ${ }^{3}$ syaiful.hendra.garuda@gmail.com, ${ }^{4}$ asmi_yuli@yahoo.co.id \\ * corresponding author
}

ARTICLE INFO

Article history

Received

Revised

Accepted

Keywords

Wind

Fetch

Wave

Return Periode

Toaya Beach

\begin{abstract}
Introduction: Toaya is one of the villages located in Sindue District, Donggala Regency, which along the village is located in the coastal area of the high seas. Donggala Regency is the oldest port city in Central Sulawesi Province, whose territory has a long coastal area of $400 \mathrm{~km}$. The waves that occur in the ocean are mainly caused by the influence of the wind. Method: This study aims to obtain wave heights that occur at Toaya Beach and can predict waves that occur with a return period of the next few years period $(2,5,10,25,50,100)$ years using the Gumbel Method and Fisher Typpet-Type 1 Method. Results and Discussion: Results of the analysis found that the significant wave height $(\mathrm{Hs})=$ $1.65 \mathrm{~m}$ and the significant wave period $(\mathrm{Ts})=7.05$ seconds in 2013 in the northwest direction. For the analysis of the frequency distribution using the Gumbel method at a return period of 2 years $=1.45 \mathrm{~m}$, at a return period of 5 years $=1.59 \mathrm{~m}$, at a return period of 10 years $=1.69$ $\mathrm{m}$, at a return period of 25 years $=1.80 \mathrm{~m}$, at the return period of 50 years $=1.89 \mathrm{~m}$ and at the return period of 100 years $=1.98 \mathrm{~m}$ while the frequency distribution analysis using the Fisher Tippet Type-1 method at the return period of 2 years $=1.45 \mathrm{~m}$, at the return period of 5 years $=$ $1.56 \mathrm{~m}$, at a return period of 10 years $=1.63 \mathrm{~m}$, at a return period of 25 years $=1.72 \mathrm{~m}$, at a return period of 50 years $=1.79 \mathrm{~m}$ and at a return period of 100 years $=1.86 \mathrm{~m}$. Conclusion: From the results of the discussion and analysis carried out, it can be concluded that from the UA value obtained from $2009-2018$ and the data fetch at the research location, it is obtained that the significant wave height value and the maximum significant wave period in 2013 in the northwest direction are $\mathrm{Hs}=1.65 \mathrm{~m}$ and $\mathrm{Ts}=7.05$ seconds.
\end{abstract}

This is an open-access article under the CC-BY-SA license.

\section{Introduction}

Indonesia is one of the regions of Southeast Asia, most of which is a marine area. Around $80 \%$ of the Indonesian people are fishermen who depend on the marine commodity industry for their livelihoods [1]. However, Indonesia is vulnerable to sea-level rise, earthquakes, and tsunamis [2][4]. Coastal areas in the Central Sulawesi Region have many uses, including tourist attractions, fishing villages, pond areas, state roads, and so on. Therefore, coastal areas need to be protected from the risk of damage and the danger of abrasion/erosion and sedimentation at river mouths [5].

Ocean waves are an up and down movement of seawater without being accompanied by a mass transfer of water. The ocean waves have dimensions in the form of wave period (T), wavelength, wave height, and wave speed [6]. The ocean waves are a phenomenon of periodic rising and falling of water that can be found in almost all places in the world. Toaya is one of the villages located in 
Sindue District, Donggala Regency, which along the village is located in the coastal area of the high seas. Donggala Regency is the oldest port city in Central Sulawesi Province, whose territory has a long coastal area of $400 \mathrm{~km}$. The waves that occur in the ocean are mainly caused by the influence of the wind. The occurrence of waves is caused by stress from the wind acting on the sea surface. So, if the wind strength is large, the waves that occur are also large [7]. The wind over the ocean transfers its energy to the waters, causing ripples, hills, and turning into what we call waves [8]. Information about wind and waves is the most important part that affects various types of activities at sea [9].

According to [10], waves caused by wind are an important part of coastal and marine areas. Ocean wave information can be obtained by conducting field measurements, but it costs a lot because it requires equipment, mastery of technology, measurements in the long term, and the field is not easy. With the existence of sufficient wind data to forecast waves with a certain return period for both the short and long term, optimal, economic and efficient planning results will be obtained [11]. In predicting wave height based on wind data, three parameters are needed, namely: wind speed $(\mathrm{u})$, the length of the area affected by the wind (Fetch area $(\mathrm{F}))$, the length of the wind blowing (wind duration $(\mathrm{t})$ ) and a map of the study area [12]. The purpose of this study was to analyze a certain return period, namely, the wave height using the Gumbel Method and the Fisher Tippet-Type 1 Method in Toaya Coastal Waters, Sindue District, Donggala Regency.

The purpose of this study was to determine the significant wave height $(\mathrm{Hs})$ and significant wave period (Ts) that occurred on Toaya Beach and to obtain the wave height that occurred at Toaya Beach and be able to predict waves that occurred with a return period in the next few years period $(2,5,10,25,50,100)$ years.

\section{Method}

\section{1 Data collection}

The data used in this study is secondary data which is the result of measurements and records obtained from the ECMWF (European Center for Medium-range Weather Forecast). The data needed are:

1. Wind Data

The wind data in this paper were collected based on hourly wind data obtained from ECMWF data for ten years of observation, namely $2009-2018$.

2. Fetch data

The data fetch is the length of the wave forming region.

3. Thematic Maps

Thematic Map is a map of the earth (.dwg file) that is used to calculate the fetch wave generation area.

\subsection{Data Management}

At the data processing stage, after all, supporting data has been obtained, it is then processed to obtain the desired parameters for research results.

\section{Wind Data Management}

Collect hourly wind data for ten years. With the wind data for these hours, it will be possible to know the wind with the daily average wind speed. Then the data is processed and can be presented in the form of a wind rose so that the wind characteristics on Toaya Beach can be read quickly. Based on wind data obtained from wind data measurements carried out on land. Therefore, it is necessary to transform from wind data over land closest to the study location to wind data above sea level.

2. Wave Data Management

Wind data for ten years to forecast waves so as to produce the height and period of deep-sea waves. As for wave forecasting, the wind data on land is transformed into wind data at sea; then, the wind stress factor is given with the fetching price. From the value of the voltage and the fetching price, the wave height and period of the wave are found by using a wave forecasting chart. The data taken were used to determine the type of waves at the research site using the Gumbel Method and the Fisher Tippet-Type 1 Method. 


\subsection{Data Analysis}

The writing process starts from the study of literature, data collection. Then it is processed so that the value of significant wave height (Hs) and significant wave period (Ts) is obtained, analysis of the frequency of ocean waves with a return period using the Gumbel Method and Fisher TippetType 1. After analyzing the data processing, the results and discussion, and conclusions will be obtained. It can be seen in full in Fig 1, 2, and 3 below.

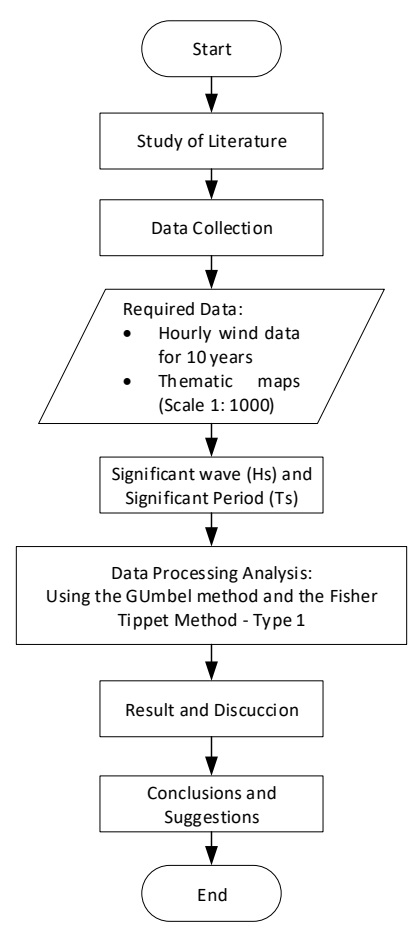

Fig 1. Research Flowchart

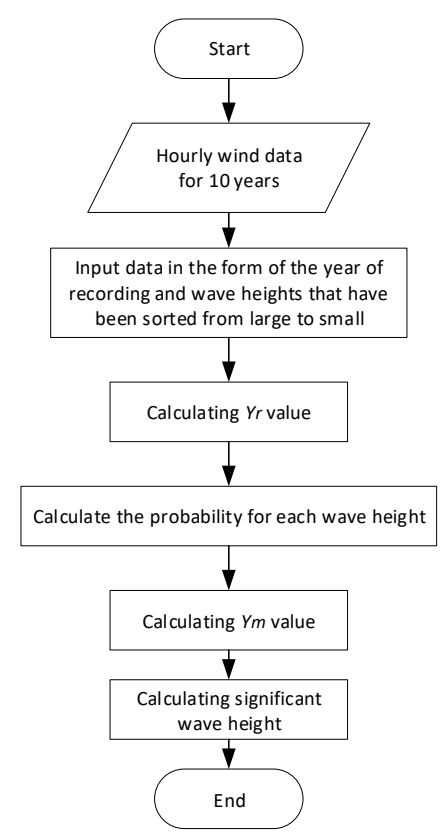


Fig 2. Flowchart Data Processing Using Fisher Tippet-Type 1 Method

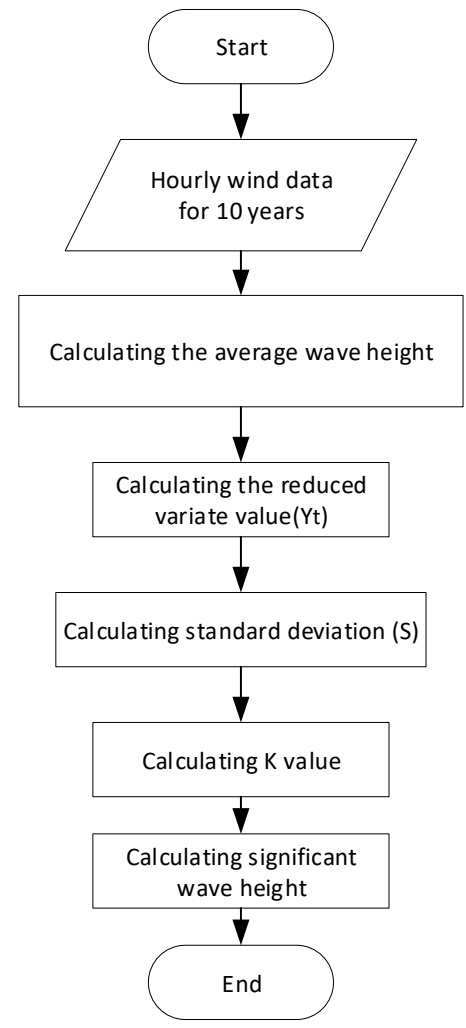

Fig 3. Flowchart Data Processing With Gumbel Method

\section{Results and Discussion}

Data entered in the WRPLOT application and worksheets (spreadsheets). This data contains the year, month, date, hour, wind direction, and wind speed. Determine the direction of the wind in the form of symbols. The wind data required are wind direction and speed data. The data is obtained from ECMWF, namely from 2009-2018.

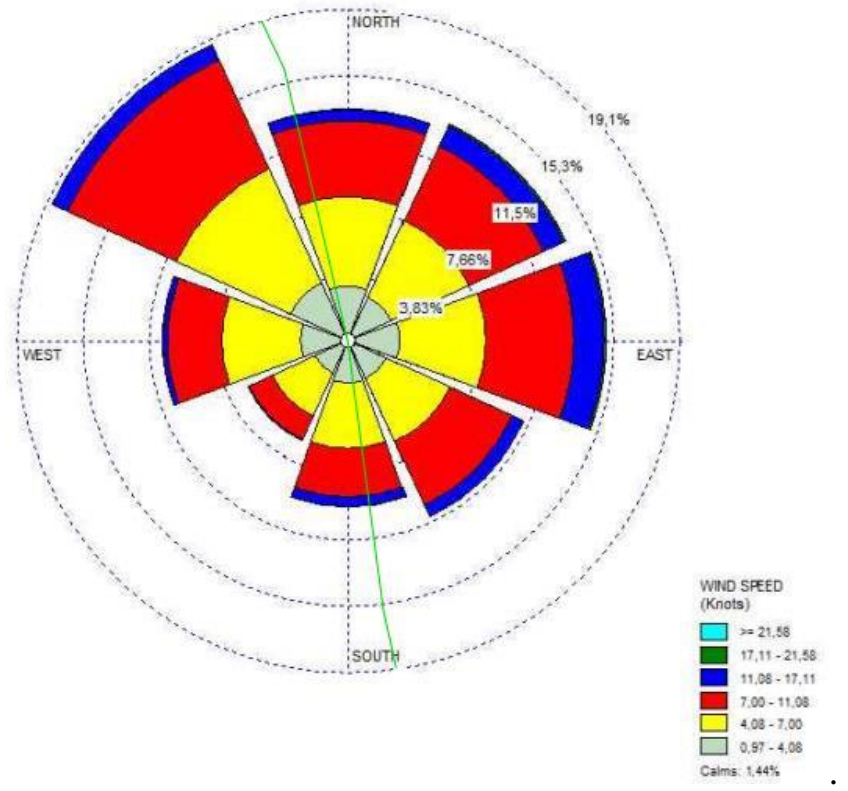

Fig 4. Windrose 10 Years (2009-2018) 
Calculation of Length Xi (Length of fetch) from different directions possible can be seen in Table 1.

\begin{tabular}{|c|c|c|c|c|c|c|}
\hline Direction & $\begin{array}{c}\text { Corne } \\
\mathbf{r}\end{array}$ & $X \mathbf{i}(\mathbf{m})$ & $\mathbf{a}$ & $\cos \mathbf{a}$ & $X \mathbf{i} \cdot \cos \mathbf{a}$ & $F \operatorname{eff}(\mathrm{m})$ \\
\hline \multirow{13}{*}{ Nort } & 340 & 4057 & -20 & 0,940 & 3812 & \multirow{13}{*}{680} \\
\hline & 345 & 2226 & -15 & 0,966 & 2150 & \\
\hline & 350 & - & -10 & 0,985 & - & \\
\hline & 355 & - & -5 & 0,996 & - & \\
\hline & 0 & - & 0 & 1,000 & - & \\
\hline & 5 & - & 5 & 0,996 & - & \\
\hline & 10 & - & 10 & 0,985 & - & \\
\hline & 15 & - & 15 & 0,966 & - & \\
\hline & 20 & - & 20 & 0,940 & - & \\
\hline & 160 & - & -20 & 0,940 & - & \\
\hline & 165 & - & -15 & 0,966 & - & \\
\hline & 170 & - & -10 & 0,985 & - & \\
\hline & 175 & 23474 & -5 & 0,996 & 23385 & \\
\hline \multirow[t]{9}{*}{ South } & 180 & 19165 & 0 & 1,000 & 19165 & \multirow[t]{9}{*}{10330} \\
\hline & 185 & 14584 & 5 & 0,996 & 14529 & \\
\hline & 190 & 12350 & 10 & 0,985 & 12162 & \\
\hline & 195 & 11764 & 15 & 0,966 & 11363 & \\
\hline & 200 & 10663 & 20 & 0,940 & 10020 & \\
\hline & 205 & 9801 & -20 & 0,940 & 9210 & \\
\hline & 210 & 9333 & -15 & 0,966 & 9015 & \\
\hline & 215 & 15352 & -10 & 0,985 & 15119 & \\
\hline & 220 & 188990 & -5 & 0,996 & 188271 & \\
\hline \multirow[t]{9}{*}{ Southwest } & 225 & 4990486 & 0 & 1,000 & 4990486 & \multirow[t]{9}{*}{200000} \\
\hline & 230 & 248233 & 5 & 0,996 & 247288 & \\
\hline & 235 & 2408200 & 10 & 0,985 & 2371614 & \\
\hline & 240 & 2125647 & 15 & 0,966 & 2053217 & \\
\hline & 245 & 11591 & 20 & 0,940 & 10892 & \\
\hline & 250 & 2034318 & -20 & 0,940 & 1911634 & \\
\hline & 255 & 1888793 & -15 & 0,966 & 1824434 & \\
\hline & 260 & 1549237 & -10 & 0,985 & 1525701 & \\
\hline & 265 & 1264584 & -5 & 0,996 & 1259772 & \\
\hline \multirow[t]{9}{*}{ West } & 270 & 258566 & 0 & 1,000 & 258566 & \multirow[t]{9}{*}{200000} \\
\hline & 275 & 244456 & 5 & 0,996 & 243526 & \\
\hline & 280 & 267133 & 10 & 0,985 & 263075 & \\
\hline & 285 & 265864 & 15 & 0,966 & 256805 & \\
\hline & 290 & 271932 & 20 & 0,940 & 255532 & \\
\hline & 295 & 270948 & -20 & 0,940 & 254608 & \\
\hline & 300 & 269629 & -15 & 0,966 & 260442 & \\
\hline & 305 & 268365 & -10 & 0,985 & 264288 & \\
\hline & 310 & 262121 & -5 & 0,996 & 261124 & \\
\hline
\end{tabular}


Northwest

\begin{tabular}{rrrrl}
\hline 315 & 221001 & 0 & 1,000 & 221001 \\
\hline 320 & 204609 & 5 & 0,996 & 203830 \\
\hline 325 & 191778 & 10 & 0,985 & 188864 \\
\hline 330 & 193397 & 15 & 0,966 & 186807 \\
\hline 335 & 504769 & 20 & 0,940 & 474328 \\
\hline
\end{tabular}

200000

The results of wave analysis between observational data and secondary data using the Gumbel Method and the Fisher Tippet-Type 1 method did not show a significant difference. The data used to compare the wave height between the Gumbel Method and the Fisher Tippet-Type 1 method are observational data and secondary data. The accuracy of Gumbel's Method and Fisher's Tippet-Type 1 method was calculated using the Root Mean Square (RMSE). As shown in Table 2 and Table 3 below:

Table 2. Gumbel Method RMSE Calculation Results

\begin{tabular}{|c|c|c|c|}
\hline \multirow{2}{*}{ Direction } & \multicolumn{3}{|c|}{ Gumbel Method } \\
\cline { 2 - 4 } & $\begin{array}{c}\text { Observation Data (Yi) } \\
(\mathrm{m})\end{array}$ & $\begin{array}{c}\text { Prediction Data (Yi) } \\
(\mathrm{m})\end{array}$ & $\begin{array}{c}(\mathrm{Yi}-\mathrm{Yi})^{2} \\
(\mathrm{~m})\end{array}$ \\
\hline Nort & 1,25 & 0,08 & 1,37 \\
\hline Nort & 1,25 & 0,09 & 1,34 \\
\hline Nort & 1,25 & 0,10 & 1,32 \\
\hline Nort & 1,25 & 0,11 & 1,30 \\
\hline Nort & 1,25 & 0,12 & 1,28 \\
\hline Nort & 1,25 & 0,13 & 1,27 \\
\hline
\end{tabular}

Table 3. RMSE Calculation Results in Fisher Tippet-Type 1 . Method

\begin{tabular}{|c|c|c|c|}
\hline \multirow{2}{*}{ Direction } & \multicolumn{3}{|c|}{ Fisher Tippet-Type 1 Methods } \\
\cline { 2 - 4 } & $\begin{array}{c}\text { Observation Data (Yi) } \\
(\mathrm{m})\end{array}$ & Prediction Data (Yi) (m) & $\begin{array}{c}(\text { Yi-Yi) } \\
(\mathrm{m})\end{array}$ \\
\hline Nort & 1,25 & 0,08 & 1,37 \\
\hline Nort & 1,25 & 0,09 & 1,35 \\
\hline Nort & 1,25 & 0,10 & 1,33 \\
\hline Nort & 1,25 & 0,10 & 1,32 \\
\hline Nort & 1,25 & 0,11 & 1,30 \\
\hline Nort & 1,25 & 0,11 & 1,29 \\
\hline \multicolumn{2}{|c|}{$1,152 \mathrm{~m}$} & 7,96 \\
\hline
\end{tabular}

From Table 2 and Table 3, it can be seen that the Gumbel method obtained an RMSE value of $1.146 \mathrm{~m}$ while the Fisher Tippet-Type 1 method obtained an RMSE value of $1.152 \mathrm{~m}$. The results obtained indicate that the Gumbel method is more accurate. 


\section{Conclusion}

From the results of the discussion and analysis carried out, it can be concluded that from the UA value obtained from $2009-2018$ and the data fetch at the research location. It is obtained that the significant wave height value and the maximum significant wave period in 2013 in the northwest direction are $\mathrm{Hs}=1.65 \mathrm{~m}$ and $\mathrm{Ts}=7.05$ seconds. Predict the recurrence wave that occurs, the Gumbel method and the Fisher Tippet-Type 1 method are used. So that the following values are obtained For the Gumbel method, the highest return period value is in the northwest direction, namely two years $=1.45 \mathrm{~m}$, for a five year return period $=1.59 \mathrm{~m}$, for a ten year return period $=$ $1.69 \mathrm{~m}$, for a 25 year return period $=1.80 \mathrm{~m}$, at the return period of 50 years $=1.89 \mathrm{~m}$ and at the return period of 100 years $=1.98 \mathrm{~m}$ and For the Fisher Tippet-Type 1 method, the highest return period value is in the northwest direction, namely two years $=1.45 \mathrm{~m}$, in the five year return period $=1.56 \mathrm{~m}$, in the ten year return period $=1.63 \mathrm{~m}$, in the return period 25 years $=1.72 \mathrm{~m}$, at a return period of 50 years $=1.79 \mathrm{~m}$ and at a return period of 100 years $=1.86 \mathrm{~m}$.

\section{Acknowledgment}

This researcher would like to thank all those who have helped in this research, especially the government of Toaya Village, Sindue District, Donggala Regency, Central Sulawesi.

\section{References}

[1] C. Warren and D. J. Steenbergen, "Fisheries decline, local livelihoods, and conflicted governance: An Indonesian case," Ocean Coast. Manag., vol. 202, p. 105498, 2021, DOI: 10.1016/j.ocecoaman.2020.105498.

[2] S. Widiyantoro et al., "Implications for megathrust earthquakes and tsunamis from seismic gaps south of Java Indonesia," Sci. Rep., vol. 10, no. 1, pp. 1-11, 2020, DOI: 10.1038/s41598-020-72142$\mathrm{z}$.

[3] S. K. Kafle, "Rapid Disaster Risk Assessment of Coastal Communities: A Case Study of Mutiara Village, Banda Aceh, Indonesia.," Int. Conf. Environ. Disaster Manag. Indonesia. December 5-8, pp. $1-14,2006$.

[4] Z. Imran, S. W. Sugiarto, and A. N. Muhammad, "Coastal vulnerability index aftermath tsunami in Palu Bay, Indonesia," IOP Conf. Ser. Earth Environ. Sci., vol. 420, no. 1, 2020, DOI: 10.1088/17551315/420/1/012014.

[5] S. Suharti, L. Andadari, I. Yeny, D. Yuniati, and R. Agustarini, "Vague property status and future risk of mangroves: Lesson learned from South Sulawesi, Indonesia," IOP Conf. Ser. Earth Environ. Sci., vol. 648, no. 1, 2021, DOI: 10.1088/1755-1315/648/1/012047.

[6] M. H. Derkani et al., "Observations from the Antarctic Circumnavigation Expedition," Earth Syst. Sci. Data, no. October, pp. 1-22, 2020, DOI: doi.org/10.5194/essd-2020-255.

[7] Y. Shin, A. Cifuentes-Lorenzen, M. M. Howard Strobel, and J. O'Donnell, "Waves in Western Long Island Sound: A Fetch-Limited Coastal Basin," J. Geophys. Res. Ocean., vol. 126, no. 2, 2021, DOI: 10.1029/2020JC016468.

[8] L. Cavaleri et al., "Wave modeling - The state of the art," Prog. Oceanogr., vol. 75, no. 4, pp. 603674, 2007, DOI: 10.1016/j.pocean.2007.05.005.

[9] A. Toffoli and E. M. Bitner-Gregersen, "Types of Ocean Surface Waves, Wave Classification," Encycl. Marit. Offshore Eng., pp. 1-8, 2017, doi: 10.1002/9781118476406.emoe077.

[10] T. J. Thomas and G. S. Dwarakish, "Numerical Wave Modelling - A Review," Aquat. Procedia, vol. 4, no. Icwrcoe, pp. 443-448, 2015, DOI: 10.1016/j.aqpro.2015.02.059.

[11] Sara and winter, Metocean Procedures Guide for Offshore Renewables Offshore Renewables Special Intrest Group, no. 2. 2018.

[12] M. R. Lessy and R. M. Abdullah, "Forecasting of Significant Wave Height and Period at Western Waters of Ternate Island, North Maluku," Techno J. Penelit., vol. 10, no. 1, pp. 17-26, 2021, [Online]. Available: https://ejournal.unkhair.ac.id/index.php/Techno/article/view/3026. 